\title{
EFFECT OF SUPPLEMENTATION WITH COPPER IN DIFFERENT CHEMICAL FORMS ON SELECTED PHYSIOLOGICAL BLOOD MARKERS AND CONTENT OF MINERALS IN SELECTED TISSUES OF TURKEYS
}

\author{
Bogusław Makarski, Mateusz Gortat \\ Chair of Biochemistry and Toxicology \\ University of Life Science in Lublin
}

\begin{abstract}
Scientific research has demonstrated that different compounds containing copper are capable of stimulating body weight gains, improving the health of animals and attaining high production performance without causing excessive accumulation of various chemical compounds in animal tissues. Besides, copper has been reported to exert a positive effect on the immune system, haematological blood markers and the microbiological balance in the gastrointestinal tract of turkeys.

The experiment was conducted on 60 BUT-9 line turkeys. The birds were divided into 5 experimental groups. Each group included 12 turkeys kept in cages. The bird were reared for 19 weeks. The first group served as control. Group II received $\mathrm{CuSO}_{4}$ added to water in a dose of $10 \mathrm{mg} \mathrm{Cu} \mathrm{dm}{ }^{-3} \mathrm{H}_{2} \mathrm{O}$. Group III was com posed of birds administered a $\mathrm{Cu}$ chelate with lysine in a dose of $10 \mathrm{mg} \mathrm{Cu} \mathrm{dm}{ }^{-3} \mathrm{H}_{2} \mathrm{O}$. Group IV received $\mathrm{CuSO}_{4}$ in a dose of $20 \mathrm{mg} \mathrm{Cu} \mathrm{dm} \mathrm{m}^{-3} \mathrm{H}_{2} \mathrm{O}$, whereas group $\mathrm{V}$ were given a $\mathrm{Cu}$-lysine supplement in a dose of $20 \mathrm{mg} \mathrm{Cu} \mathrm{dm}{ }^{-3} \mathrm{H}_{2} \mathrm{O}$. The birds were fed commercial complete feed mixes. The copper preparations were added to drinking water since the $3^{\text {rd }}$ week of rearing. The objective of this study has been to determine the effect of $\mathrm{Cu}$ supplementation in the organic and inorganic form and in two doses on the health of birds and on accumulation of minerals in their breast muscle and liver. Further analyses involved the determination of haematological and biochemical markers in blood as well as assays of selected minerals in the birds' blood, breast muscle and liver. The analysis of the results indicated that the doses of copper improved the health of the turkeys, as verified by better haematological markers. Statistically significant difference appeared in the group receiving $20 \mathrm{mg} \mathrm{Cu} \mathrm{dm}{ }^{-3}$
\end{abstract}

prof. dr hab. Bogusław Makarski, Chair of Biochemistry and Toxicology, University of Life Science in Lublin, Akademicka 13, 20-950 Lublin, Poland 
$\mathrm{H}_{2} \mathrm{O}$ irrespective of the chemical form in which copper was administered. The study also shows that $\mathrm{Cu}$ supplementation has a significant effect on the metabolism of lipids and a non-significant impact on the content of mineral elements in the analyzed tissues. It was not until the $20 \mathrm{mg}$ dose of $\mathrm{Cu}$ as a chelate had been applied that the accumulation of copper in the turkey's liver was enhanced.

Key words: turkeys, copper, blood haematology and biochemistry, mineral elements in tissues, body weight gains.

\title{
WPLYW SUPLEMENTACJI MIEDZIĄ PODAWANĄ W RÓŻNYCH FORMACH CHEMICZNYCH NA WYBRANE WSKAŹNIKI FIZJOLOGICZNE KRWI ORAZ ZAWARTOŚĆ PIERWIASTKÓW MINERALNYCH W WYBRANYCH TKANKACH INDYKÓW
}

\begin{abstract}
Abstrakt
Z badań naukowych wynika, że różne związki miedzi można zaliczyć do substancji stymulujących przyrosty masy ciała oraz poprawiających zdrowotność zwierząt, co sprzyja uzyskiwaniu lepszych efektów produkcyjnych, nie powodując nadmiernego akumulowania związków chemicznych w tkankach zwierząt. Ponadto miedź korzystnie wpływa na funkcjonowanie układu immunologicznego, poprawia wskaźniki hematologiczne krwi oraz umożliwia utrzymanie równowagi mikrobiologicznej przewodu pokarmowego indyków.

Badania przeprowadzono na 60 indykach linii BUT-9 podzielonych na 5 grup doświadczalnych. Każda grupa liczyła po 12 indyków, które były utrzymane w klatkach. Odchów zwierząt trwał 19 tygodni. Pierwsza grupa stanowiła kontrolę. Grupa II otrzymywała dodatek $\mathrm{CuSO}_{4}$ do wody w ilości $10 \mathrm{mg} \mathrm{Cu} \mathrm{dm}{ }^{-3} \mathrm{H}_{2} \mathrm{O}$, grupa III - dodatek chelatu $\mathrm{Cu}$ z lizyna w dawce $10 \mathrm{mg} \mathrm{Cu} \mathrm{dm}{ }^{-3} \mathrm{H}_{2} \mathrm{O}$, grupa IV - dodatek $\mathrm{CuSO}_{4} \mathrm{w}$ dawce $20 \mathrm{mg}$, grupa $\mathrm{V}$ suplement $\mathrm{Cu}$ - lizynę w dawce $20 \mathrm{mg} \mathrm{Cu} \mathrm{dm}{ }^{-3} \mathrm{H}_{2} \mathrm{O}$. Paszę stanowiła typowa mieszanka pełnoporcjowa dostępna na rynku. Preparaty miedzi dodawano do wody pitnej od 3. tygodnia odchowu. Celem badań było określenie wpływu suplementacji $\mathrm{Cu}$ stosowanej $\mathrm{w}$ formie nieorganicznej i organicznej oraz w dwóch różnych dawkach na zdrowotność indyków oraz stopień akumulacji elementów mineralnych w mięśniu piersiowym i wątrobie. W badaniach oznaczono wskaźniki hematologiczne i biochemiczne krwi indyków oraz zawartość wybranych elementów mineralnych we krwi, mięśniu piersiowym i wątrobie ptaków. Wykazano, że zastosowane dawki miedzi spowodowały poprawę stanu zdrowia indyków, co wyrażało się korzystnymi zmianami wskaźników hematologicznych. Statystycznie istotne wartości odnotowano w grupie ptaków, które otrzymywały $20 \mathrm{mg} \mathrm{Cu} \mathrm{dm}{ }^{-3} \mathrm{H}_{2} \mathrm{O}$ niezależnie od formy chemicznej. Z badań wynika, że suplementacja $\mathrm{Cu}$ ma znaczący wpływ na gospodarkę lipidowa. Miedź miała nieznaczny wpływ na zawartość elementów mineralnych w tkankach. Jedynie dawka $20 \mathrm{mg} \mathrm{Cu}$ w formie chelatu spowodowała zwiększona kumulację tego pierwiastka w wątrobach ptaków.
\end{abstract}

Słowa kluczowe: indyki, miedź, hematologia i biochemia krwi, elementy mineralne w tkankach, przyrosty.

\section{INTRODUCTION}

In poultry breeding practice, much attention is paid to the proper feeding of birds and rational use of feed supplements supposed to increase productivity, which is necessitated by legal regulations, economic considerations 
and protection of consumers' health (JAMroz, Potkański 2004). Changes in the law governing the use of drugs in animal breeding for human consumption have forced the breeders to apply supplementation which is consistent with the currently binding regulations and which helps to improve the health of animals and to attain high production performance without causing excessive accumulation of various chemical compounds in animal tissues (OLEJNIK et al. 2009). This fact has contributed to an increased interest in nonantibiotic growth stimulators, which are not a health hazard to consumers (Noyce et al. 2006). Scientific research has demonstrated that different compounds containing copper are capable of stimulating body weight gains and improving feed utilization (Harms, Buresh 1986, Pesti, BaKali 1996, SmulikowSKA 1996). The stimulating effects of copper are claimed to be produced owing to improved hematological blood markers (JAMROZ 1990, MAKARSKI et al. 2002). Other authors additionally point to the contribution of copper to the synthesis and activation of many enzymes (BoGuszewskA et al. 2003). This element has been reported to exert a positive effect on the immune system by stimulating the biosynthesis of antibodies (FAILLA et al. 1998) as well as by inhibiting the growth of pathogenic microorganisms (BRUNCH et al. 1965, Jamroz, Potkański 2004, Noyce et al. 2006, Kuźlik-Wyrostek, Makarski 2009). In turn, a study conducted by MAKARSKI (2002) demonstrated that the application of copper modified the composition of bacterial flora in the gastrointestinal tract of turkeys. Consequently, copper supplementation enabled the birds to maintain the microbiological balance, which has an indirect, positive effect on body functions, also improving body weight gains.

The objective of this study has been to determine the effect of copper supplementation in two chemical forms and in various doses on levels of selected hematological and biochemical blood markers of turkeys. In order to assess accumulation of minerals in tissues, levels of minerals were assayed in blood, breast muscle and liver of the birds.

\section{MATERIAL AND METHODS}

The experimental material were 60 BUT-9 line turkeys reared for 19 weeks. The birds were divided into 5 experimental groups. The first group served as control. Group II received $\mathrm{CuSO}_{4}$ added to drinking water in a dose of $10 \mathrm{mg} \mathrm{Cu} \mathrm{dm}{ }^{-3} \mathrm{H}_{2} \mathrm{O}$. Group III consisted of birds administered supplementary $\mathrm{Cu}$ chelate with lysine in a dose of $10 \mathrm{mg} \mathrm{Cu} \mathrm{dm}^{-3} \mathrm{H}_{2} \mathrm{O}$. Group IV received $\mathrm{CuSO}_{4}$ in a dose of $20 \mathrm{mg} \mathrm{Cu} \mathrm{dm}{ }^{-3} \mathrm{H}_{2} \mathrm{O}$, whereas the group $\mathrm{V}$ birds were given Cu-lysine supplement in a dose of $20 \mathrm{mg} \mathrm{Cu} \mathrm{dm}{ }^{-3} \mathrm{H}_{2} \mathrm{O}$. The experimental preparations were administered with drinking water to eliminate the antagonistic effect of feed mix ingredients on the availability of this element (Noy et al. 1994). 
Each group included 12 turkeys kept in cages. All birds were provided identical zoohygienic conditions, pursuant to the requirements for slaughter turkey rearing. The birds had an ad libitum access to feed and water. They were kept on straw litter and fed typical complete feed mixes available on the Polish market. The quality of water used in the experiment met sanitary requirements stipulated in the Regulation of the Ministry of Health and Environmental Protection (MZiOS) of $4^{\text {th }}$ May 1990 (Journal of Law no 3 , item 250/1990) and the requirements set up for water for drinking and household purposes.

Before slaughter, in the $19^{\text {th }}$ week of life, blood was sampled from the brachial vein for haematological and biochemical analyses. Haematological markers, including red blood cells (RBC) count, haemoglobin $(\mathrm{Hb})$ and haematocrit $(\mathrm{Ht})$, were determined in the blood samples according to the clinical methods. In addition, an automatic blood analyzer Hitachi 704 was used to assay the following biochemical parameters in serum: aspartate aminotransferase (AST), alanine aminotransferase (ALT), total cholesterol (CHOL), uric acid (UA), triacylglycerols (TG), glucose (GLU) as well as the content of mineral elements in blood ( $\mathrm{Ca}, \mathrm{Mg}$ and $\mathrm{P}$ ). All analyses were carried out with reagents produced by the company called Katal. The concentrations of $\mathrm{Fe}, \mathrm{Cu}$ and $\mathrm{Zn}$ were determined directly from serum after dilution (1:4) by means of the ASA method.

The slaughter was followed by detailed dissection, during which samples of liver and breast muscle were collected for analyses. All samples were individually marked, packed in plastic bags, tagged and frozen at $-18^{\circ} \mathrm{C}$. According to the design of the experiment, samples of liver and breast muscle were determined for concentrations of $\mathrm{Zn}, \mathrm{Cu}, \mathrm{Mn}, \mathrm{Fe}, \mathrm{P}, \mathrm{K}, \mathrm{Ca}$, and $\mathrm{Mg}$. These determinations were carried out on standardized and thoroughly comminuted turkey tissues, from which 1-g samples were collected for analyses. Next, weighed portions of the analytical material were transferred into glass thimbles, to which $5 \mathrm{ml}$ of $70 \% \mathrm{HClO}_{4}$ and $65 \% \mathrm{HNO}_{3}$ in a 1:5 ratio were added. Afterwards, the thimbles were placed in a mineralizer, and the samples were mineralized first at $80^{\circ} \mathrm{C}$ for $60 \mathrm{~min}$, and then at $200^{\circ} \mathrm{C}$ for ca 90 min. The resultant solution was transferred to a measuring flask, which was filled up to $50 \mathrm{ml}$ with redistilled $\mathrm{H}_{2} \mathrm{O}$. The solution thus prepared was assayed for the concentration of $\mathrm{Cu}$ using an atomic absorption spectrophotometer (AAS) on a UNICAM 939 apparatus. Concentrations of the other elements, i.e. $\mathrm{Ca}, \mathrm{Fe}, \mathrm{Zn}$, and $\mathrm{Mg}$, were assayed with the use of an SP9 AS atomic absorption spectrophotometer by Unicam. The complete feed mixes applied in the experiment were also analyzed for the content of major minerals, i.e. $\mathrm{Cu}, \mathrm{Zn}, \mathrm{Mn}, \mathrm{Fe}, \mathrm{Ca}$, and $\mathrm{Mg}$, following the above procedures.

The experimental data underwent statistical analysis with Statistica 5.0 PL 97 software, using a one-way analysis of variance at significance levels of 0.05 and 0.01 . 


\section{RESULTS AND DISCUSSION}

The biological experiment discussed in this paper has involved the application of five types of complete feed mixes, whose nutritive value was balanced depending on the age and physiological needs of turkeys. The composition of the feed mixes declared by the producer is presented in Table 1.

Table 1

Nutritive value of the complete mixes for turkeys

\begin{tabular}{|l|c|c|c|c|c|}
\hline \multicolumn{1}{|c|}{ Feeding period } & $0-3$ week & $4-6$ week & $7-10$ week & $11-14$ week & $15-19$ week \\
\hline $\begin{array}{l}\text { Metabolizable energy } \\
\text { (kcal kg-1) }\end{array}$ & 2800 & 2900 & 3000 & 3075 & 3150 \\
\hline Total protein (\%) & 27.00 & 25.50 & 23.00 & 21.00 & 18.00 \\
\hline Raw fibre (\%) & 4.00 & 3.50 & 3.50 & 4.00 & 4.00 \\
\hline Lysine (\%) & 1.70 & 1.60 & 1.45 & 1.30 & 1.10 \\
\hline Methionine (\%) & 0.62 & 0.62 & 0.57 & 0.54 & 0.50 \\
\hline Methionine + cystine (\%) & 1.10 & 1.02 & 0.96 & 0.91 & 0.82 \\
\hline Tryptophan (\%) & 0.32 & 0.26 & 0.25 & 0.22 & 0.19 \\
\hline Calcium (\%) & 1.30 & 1.30 & 1.15 & 1.10 & 1.00 \\
\hline Available phosphorus (\%) & 0.70 & 0.65 & 0.63 & 0.60 & 0.58 \\
\hline Sodium (\%) & 0.15 & 0.16 & 0.15 & 0.15 & 0.15 \\
\hline
\end{tabular}

The feed mixes were tested for their content of selected mineral elements, i.e.: $\mathrm{Cu}, \mathrm{Zn}, \mathrm{Mn}, \mathrm{Fe}, \mathrm{K}$, and $\mathrm{Mg}$, and the results are given in Table 2 . The analysis of these results demonstrated that the content of minerals in the feed mixes was above the recommended levels (KRATZER et al. 1994), but not toxic (Noy et al. 1994). According to SMUlikowska (1996), the recommended dose of copper is 10 to $20 \mathrm{mg} \mathrm{kg}^{-1}$ whereas Polonis et al. (1999) indicate that for growing turkeys this dose may be as high as $20-30 \mathrm{mg} \mathrm{kg}^{-1}$.

Table 3 presents the final body weights of turkey hens after 19 weeks of rearing. The experimental factors applied in the particular groups did not cause increased body weight gains of turkey hens as compared to the control group. The results just imply a growing tendency along with an increasing dose of copper in particular groups. However, the recorded differences were statistically insignificant. Other investigations (MAKARSKI, ZADURA, 2006) demonstrated that copper addition in the organic form and in a dose of $10 \mathrm{mg} \mathrm{dm}-3 \mathrm{H}_{2} \mathrm{O}$ resulted in a significant increase in body weight of turkeys as compared to the control birds.

Haematological blood analyses are the basic source of information on the health of an animal. Table 4 presents levels of haematological blood 
Mineral elements in the feed mixes for turkeys

\begin{tabular}{|l|c|c|c|c|c|c|}
\hline \multirow{2}{*}{$\begin{array}{c}\text { Feed mixes } \\
\text { (feeding } \\
\text { period) }\end{array}$} & \multicolumn{6}{|c|}{ Minerals } \\
\cline { 2 - 7 } & $\begin{array}{c}\mathrm{Cu} \\
\left(\mathrm{mg} \mathrm{kg}^{-1}\right)\end{array}$ & $\begin{array}{c}\mathrm{Zn} \\
\left(\mathrm{mg} \mathrm{kg}^{-1}\right)\end{array}$ & $\begin{array}{c}\mathrm{Mn} \\
\left(\mathrm{mg} \mathrm{kg}^{-1}\right)\end{array}$ & $\begin{array}{c}\mathrm{Fe} \\
\left(\mathrm{mg} \mathrm{kg}^{-1}\right)\end{array}$ & $\begin{array}{c}\mathrm{K} \\
\left(\mathrm{mg} \mathrm{kg}^{-1}\right)\end{array}$ & $\begin{array}{c}\mathrm{Mg} \\
\left(\mathrm{mg} \mathrm{kg}^{-1}\right)\end{array}$ \\
\hline $0-3$ week & 12.8 & 73.1 & 114.6 & 77.0 & 9.7 & 1.7 \\
\hline $4-6$ week & 13.8 & 73.0 & 118.0 & 79.0 & 11.3 & 2.0 \\
\hline $7-10$ week & 18.7 & 73.0 & 110.0 & 64.0 & 10.2 & 1.9 \\
\hline $11-14$ week & 23.9 & 77.0 & 120.0 & 62.0 & 9.4 & 1.8 \\
\hline $15-19$ week & 22.1 & 69.0 & 104.0 & 55.0 & 10.4 & 1.9 \\
\hline
\end{tabular}

Table 3

Final body weights of turkey hens after 19 weeks of rearing

\begin{tabular}{|c|c|c|c|c|c|}
\hline \multirow{4}{*}{ Indicator } & Group I & Group II & Group III & Group IV & Group V \\
\cline { 2 - 6 } & control & $\mathrm{CuSO}_{4}$ & $\begin{array}{c}\text { chelate } \\
\mathrm{Cu}-\mathrm{Lys}\end{array}$ & $\mathrm{CuSO}_{4}$ & $\begin{array}{c}\text { chelate } \\
\mathrm{Cu}-\mathrm{Lys}\end{array}$ \\
\cline { 2 - 6 } & - & \multicolumn{2}{|c|}{$10 \mathrm{mg} \mathrm{Cu} \mathrm{dm}{ }^{-3} \mathrm{H}_{2} \mathrm{O}$} & \multicolumn{2}{|c|}{$20 \mathrm{mg} \mathrm{Cu} \mathrm{dm} \mathrm{dm}^{-3} \mathrm{H}^{\mathrm{O}}$} \\
\hline Body weight (g) & $\begin{array}{c}13235.00 \\
\pm 770.00\end{array}$ & $\begin{array}{c}12180.00 \\
\pm 706.80\end{array}$ & $\begin{array}{c}12340.00 \\
\pm 1056.80\end{array}$ & $\begin{array}{c}12590.00 \\
\pm 1103.50\end{array}$ & $\begin{array}{c}13220.00 \\
\pm 1188.10\end{array}$ \\
\hline
\end{tabular}

Table 4

The level of haematological indices in blood of 16-week-old turkeys

\begin{tabular}{|c|c|c|c|c|c|}
\hline \multirow{3}{*}{ Index } & Group I & Group II & Group III & Group IV & Group V \\
\hline & control & $\mathrm{CuSO}_{4}$ & $\begin{array}{l}\text { chelate } \\
\mathrm{Cu} \text { - Lys }\end{array}$ & $\mathrm{CuSO}_{4}$ & $\begin{array}{l}\text { chelate } \\
\mathrm{Cu} \text { - Lys }\end{array}$ \\
\hline & - & \multicolumn{2}{|c|}{$10 \mathrm{mg} \mathrm{Cu} \mathrm{dm}{ }^{-3} \mathrm{H}_{2} \mathrm{O}$} & \multicolumn{2}{|c|}{$20 \mathrm{mg} \mathrm{Cu} \mathrm{dm}{ }^{-3} \mathrm{H}_{2} \mathrm{O}$} \\
\hline $\begin{array}{l}\text { RBC } \\
\left(10^{12} \mathrm{dm}^{-3}\right)\end{array}$ & $2.02^{b} \pm 0.69$ & $2.28^{a b} \pm 0.73$ & $2.35^{a b} \pm 0.69$ & $2.58 \mathrm{a} \pm 0.14$ & $2.55^{a} \pm 0.14$ \\
\hline $\mathrm{Hb}\left(\mathrm{g} \mathrm{dl}^{-1}\right)$ & $13.00 \mathrm{~b} \pm 4.30$ & $13.80^{b} \pm 4.55$ & $14.77^{b} \pm 4.31$ & $16.00 \mathrm{a} \pm 0.58$ & $15.55^{a} \pm 0.21$ \\
\hline $\mathrm{Ht}(\%)$ & $34.13^{b} \pm 11.62$ & $38.60^{a b} \pm 12.23$ & $39.45^{a b} \pm 11.66$ & $42.84 \mathrm{a} \pm 1.79$ & $42.05^{a} \pm 0.92$ \\
\hline
\end{tabular}

$a, b-$ statistically significant difference at $p \leq 0.05$

markers of the turkeys in the $19^{\text {th }}$ week of life. The results suggest that

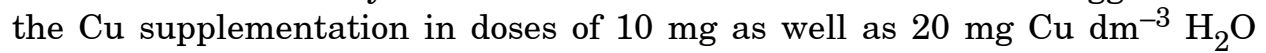
had a beneficial influence on all analyzed markers. Statistically significant differences were noted in the group of birds receiving $20 \mathrm{mg} \mathrm{Cu} \mathrm{dm}{ }^{-3} \mathrm{H}_{2} \mathrm{O}$ irrespective of the chemical form in which $\mathrm{Cu}$ was administered. The above 
results confirm the usability of copper for the biosynthesis of haeme, which improves iron utilization from feed ingested by turkeys. Similar observations were made by other authors (JAMROZ 1990, MAKARSKI et al. 2002).

Table 5 contains levels of selected biochemical serum markers of turkeys in the $19^{\text {th }}$ week of life. In order to assess toxicity of the applied copper doses, determinations were carried out on activities of blood serum enzymes. The analyses showed enhanced activity of AST in groups III and IV. With respect to the increased ALT activity, a statistically significant value was reported in the group receiving $20 \mathrm{mg} \mathrm{Cu} \mathrm{dm}{ }^{-3} \mathrm{H}_{2} \mathrm{O}$ in the organic form. The enhanced activity of both aminotransferases could be indicated by pathological lesions in livers of the birds. Their increased activity could have also been affected by other factors. The detailed post-mortem anatomopathological analysis did not demonstrate any adverse changes in the liver. It seems that in this case the enhanced activity of aminotransferases reflects enhanced biosynthesis of endogenous amino acids necessary for the synthesis of tissue proteins of turkeys. This is confirmed by the final body weight of the turkeys in the groups receiving the increased dose of copper, i.e. $20 \mathrm{mg} \mathrm{Cu} \mathrm{dm}{ }^{-3} \mathrm{H}_{2} \mathrm{O}$.

Supplementation of feed mixes with copper was observed to have raised the content of total cholesterol in blood serum of the birds. Significant differences between the control and experimental birds did not appear in the case of birds administered $20 \mathrm{mg} \mathrm{Cu} \mathrm{dm}{ }^{-3} \mathrm{H}_{2} \mathrm{O}$ in the form of Cu-lysine

Table 5

The values of biochemical indices of turkeys' blood serum

\begin{tabular}{|c|c|c|c|c|c|}
\hline \multirow{3}{*}{ Index } & Group I & Group II & Group III & Group IV & Group V \\
\hline & control & $\mathrm{CuSO}_{4}$ & $\begin{array}{l}\text { chelate } \\
\mathrm{Cu} \text { - Lys }\end{array}$ & $\mathrm{CuSO}_{4}$ & $\begin{array}{l}\text { chelate } \\
\mathrm{Cu} \text { - Lys }\end{array}$ \\
\hline & - & \multicolumn{2}{|c|}{$10 \mathrm{mg} \mathrm{Cu} \mathrm{dm}{ }^{-3} \mathrm{H}_{2} \mathrm{O}$} & \multicolumn{2}{|c|}{$20 \mathrm{mg} \mathrm{Cu} \mathrm{dm}{ }^{-3} \mathrm{H}_{2} \mathrm{O}$} \\
\hline $\operatorname{AST}\left(\mathrm{U} \mathrm{dm}^{-3}\right)$ & $\begin{array}{c}592.36^{b} \\
119.13\end{array}$ & $\begin{array}{c}526.25^{b} \\
91.33\end{array}$ & $\begin{array}{c}712.75^{a} \\
153.69\end{array}$ & $\begin{array}{c}632.67^{a} \\
129.95\end{array}$ & $\begin{array}{c}525.70^{b} \\
58.75\end{array}$ \\
\hline $\operatorname{ALT}\left(\mathrm{U} \mathrm{dm}^{-3}\right)$ & $\begin{array}{c}18.18^{b} \\
4.51\end{array}$ & $\begin{array}{c}16.25^{c} \\
4.65\end{array}$ & $\begin{array}{c}21.50^{b} \\
6.76\end{array}$ & $\begin{array}{c}20.92^{b} \\
4.64\end{array}$ & $\begin{array}{c}27.00^{a} \\
7.44\end{array}$ \\
\hline CHOL (mg dl-1) & $\begin{array}{c}177.18^{c} \\
31.00\end{array}$ & $\begin{array}{c}308.33^{b} \\
141.32\end{array}$ & $\begin{array}{c}370.17^{a} \\
107.02\end{array}$ & $\begin{array}{c}285.42^{b} \\
118.54\end{array}$ & $\begin{array}{c}109.70^{c} \\
16.51\end{array}$ \\
\hline $\mathrm{UA}\left(\mathrm{mg} \mathrm{dl}{ }^{-1}\right)$ & $\begin{array}{c}8.05^{a} \\
2.38\end{array}$ & $\begin{array}{c}6.35^{b} \\
0.87\end{array}$ & $\begin{array}{l}7.71^{a} \\
2.01\end{array}$ & $\begin{array}{c}7.70^{a} \\
1.17\end{array}$ & $\begin{array}{c}4.94^{c} \\
0.97\end{array}$ \\
\hline $\mathrm{TG}\left(\mathrm{mg} \mathrm{dl}^{-1}\right)$ & $\begin{array}{c}44.64^{a} \\
8.31\end{array}$ & $\begin{array}{c}24.33^{c} \\
7.40\end{array}$ & $\begin{array}{c}30.00^{b} \\
4.43\end{array}$ & $\begin{array}{c}31.33^{b} \\
7.60\end{array}$ & $\begin{array}{c}23.01^{c} \\
6.77\end{array}$ \\
\hline $\mathrm{GLU}\left(\mathrm{mg} \mathrm{dl}^{-1}\right)$ & $\begin{array}{c}223.73^{b} \\
58.37\end{array}$ & $\begin{array}{c}238.92^{b} \\
43.52\end{array}$ & $\begin{array}{c}217.67^{b} \\
67.00\end{array}$ & $\begin{array}{c}248.08^{b} \\
24.85\end{array}$ & $\begin{array}{c}266.87^{a} \\
31.48\end{array}$ \\
\hline
\end{tabular}

$a, b-$ statistically significant difference at $p \leq 0.05$ 
chelate. Birds from all the experimental groups were characterized by a statistically significant decrease in the content of triacylglycerols. This is a desirable development as it is associated with the suppression of lipogenesis in the liver and adipose tissues, and at the same time confirms the role of copper in regulating the blood level of glucose. No significant changes were noted in the level of glucose, except the groups receiving the higher doses of copper.

It is worth mentioning that blood serum of the birds receiving $\mathrm{Cu}$ supplement, irrespective of its dose or chemical form, contained lowered levels of uric acid, which may be explained by $\mathrm{Cu}$ suppressing deamination processes of amino acids, which in turn seems to indicate their better utilization in the biosynthesis of tissue proteins.

Supplementation with copper preparations induced modification of the mineral composition of turkeys serum. The results of the analyses are presented in Table 6. Supplementation of feed mixes with copper, irrespective of its chemical form, was observed to induce insignificant changes in the serum level of $\mathrm{Cu}$ in the experimental turkeys compared to the control birds. A considerably higher level of $\mathrm{Cu}$ in blood serum was, in turn, observed in the group administered $20 \mathrm{mg} \mathrm{Cu} \mathrm{dm}^{-3} \mathrm{H}_{2} \mathrm{O}$ in the organic form.

Table 6

The content of mineral elements in blood serum of turkeys receiving supplementation of 10 and $20 \mathrm{mg}$ copper in different chemical forms

\begin{tabular}{|c|c|c|c|c|c|}
\hline \multirow{3}{*}{ Index } & Control & $\mathrm{CuSO}_{4}$ & $\begin{array}{l}\text { Chelate } \\
\mathrm{Cu} \text { - Lys }\end{array}$ & $\mathrm{CuSO}_{4}$ & $\begin{array}{l}\text { Chelate } \\
\text { Cu - Lys }\end{array}$ \\
\hline & group I & group II & group III & group IV & group V \\
\hline & - & \multicolumn{2}{|c|}{$10 \mathrm{mg} \mathrm{Cu} \mathrm{dm}{ }^{-3} \mathrm{H}_{2} \mathrm{O}$} & \multicolumn{2}{|c|}{$20 \mathrm{mg} \mathrm{Cu} \mathrm{dm}{ }^{-3} \mathrm{H}_{2} \mathrm{O}$} \\
\hline $\mathrm{Cu}\left(\mathrm{mg} \mathrm{dl}{ }^{-1}\right)$ & $0.37^{a} \pm 0.07$ & $0.31^{a} \pm 0.02$ & $0.39^{a} \pm 0.09$ & $0.36^{a} \pm 0.13$ & $0.14^{b} \pm 0.06$ \\
\hline $\mathrm{Zn}\left(\mathrm{mg} \mathrm{dl}{ }^{-1}\right)$ & $1.56^{b} \pm 0.28$ & $2.17^{a} \pm 0.38$ & $1.47^{c} \pm 0.56$ & $2.04^{a b} \pm 0.27$ & $2.04^{a b} \pm 0.27$ \\
\hline $\mathrm{Ca}\left(\mathrm{mg} \mathrm{dl}{ }^{-1}\right)$ & $10.13^{c} \pm 1.37$ & $10.10^{c} \pm 1.19$ & $10.44^{b} \pm 1.21$ & $10.66^{a} \pm 1.06$ & $11.05^{a} \pm 1.26$ \\
\hline $\mathrm{Mg}\left(\mathrm{mg} \mathrm{dl}^{-1}\right)$ & $2.24^{b} \pm 0.48$ & $2.30^{b} \pm 0.47$ & $2.58^{b} \pm 0.43$ & $2.68^{a} \pm 0.45$ & $2.89^{a} \pm 0.66$ \\
\hline $\mathrm{P}\left(\mathrm{mg} \mathrm{dl} \mathrm{l}^{-1}\right)$ & $8.05^{a} \pm 0.97$ & $7.52^{a} \pm 1.21$ & $8.86^{b} \pm 1.44$ & $7.90^{a} \pm 1.73$ & $8.40^{b} \pm 1.66$ \\
\hline $\mathrm{Fe}\left(\mu \mathrm{g} \mathrm{dl^{-1 } )}\right.$ & $362.18^{a} \pm 39.11$ & $277.42^{c} \pm 49.58$ & $367.00^{b} \pm 79.01$ & $332.17 a \pm 75.89$ & $370.11^{b} \pm 75.60$ \\
\hline
\end{tabular}

$a, b-$ statistically significant difference at $p \leq 0.05$

However, these results are inconsistent with findings of other authors, who reported increased concentrations of this mineral element in blood serum of reared birds (HARMs, Buresh 1986, Ewing et al. 1998, Ward et al. 1998, PoloNIS et al. 1999). Noteworthy is the accumulation of this element in the breast muscle and, above all, in the liver. Attention should also be paid to the low Fe level in the group receiving $10 \mathrm{mg}$ of $\mathrm{Cu}$ in the inorganic form. Despite the reduced concentration of Fe, the level of haemoglobin in the blood serum of group II birds increased slightly compared to the birds not receiving supplementation. 
In order to asses the accumulation of minerals in muscles of the birds receiving $\mathrm{Cu}$ supplements, chemical analyses were conducted on samples of their breast muscle. The results can be found in Table 7 . They indicate that the level of $\mathrm{Cu}$ increased in the group receiving $20 \mathrm{mg} \mathrm{Cu} \mathrm{dm}{ }^{-3} \mathrm{H}_{2} \mathrm{O}$ in the form of $\mathrm{CuSO}_{4}$ and in the one administered $10 \mathrm{mg} \mathrm{Cu} \mathrm{dm}{ }^{-3} \mathrm{H}_{2} \mathrm{O}$ as a chelate, in which the $\mathrm{Cu}$ concentration was the highest. In the other groups, the analyses demonstrated a decrease in the $\mathrm{Cu}$ concentration as compared to the control group.

Table 7

The content of mineral elements in turkeys' chest muscles

\begin{tabular}{|c|c|c|c|c|c|}
\hline \multirow{3}{*}{ Index } & Control & $\mathrm{CuSO}_{4}$ & $\begin{array}{l}\text { Chelate } \\
\mathrm{Cu} \text { - Lis }\end{array}$ & $\mathrm{CuSO}_{4}$ & $\begin{array}{l}\text { Chelate } \\
\mathrm{Cu} \text { - Lis }\end{array}$ \\
\hline & group I & group II & group III & group IV & group V \\
\hline & - & \multicolumn{2}{|c|}{$10 \mathrm{mg} \mathrm{Cu} \mathrm{dm}{ }^{-3} \mathrm{H}_{2} \mathrm{O}$} & \multicolumn{2}{|c|}{$20 \mathrm{mg} \mathrm{Cu} \mathrm{dm}{ }^{-3} \mathrm{H}_{2} \mathrm{O}$} \\
\hline $\mathrm{Cu}\left(\mathrm{mg} \mathrm{kg}^{-1}\right)$ & $1.20^{a b} \pm 0.6$ & $1.00^{a b} \pm 0.1$ & $1.70^{a} \pm 0.1$ & $1.40^{a b} \pm 0.7$ & $0.80^{b} \pm 0.3$ \\
\hline $\mathrm{Zn}\left(\mathrm{mg} \mathrm{kg} \mathrm{kg}^{-1}\right)$ & $20.80^{b} \pm 1.2$ & $19.20^{b c} \pm 0.3$ & $19.50^{c} \pm 0.4$ & $19.40^{c} \pm 0.5$ & $30.40^{a} \pm 3.7$ \\
\hline $\mathrm{Ca}(\%)$ & $0.098^{c} \pm 0.035$ & $0.257 \mathrm{a} \pm 0.021$ & $0.122^{c} \pm 0.007$ & $0.209^{b} \pm 0.008$ & $0.225^{a b} \pm 0.036$ \\
\hline $\operatorname{Mg}(\%)$ & $\begin{array}{l}0.3124^{a b} \\
\pm 0.0099\end{array}$ & $\begin{array}{l}0.3143^{a b} \\
\pm 0.0123\end{array}$ & $\begin{array}{l}0.3129^{a b} \\
\pm 0.0047\end{array}$ & $\begin{array}{c}0.3423^{a} \\
\pm 0.0094\end{array}$ & $\begin{array}{c}0.2984 \mathrm{a} \\
\pm 0.0324\end{array}$ \\
\hline $\mathrm{Fe}\left(\mathrm{mg} \mathrm{kg}^{-1}\right)$ & $10.70 \pm 2.1$ & $7.2 \pm 0.7$ & $10.20 \pm 1.1$ & $10.00 \pm 3.3$ & $9.8 \pm 1.5$ \\
\hline $\mathrm{K}(\%)$ & $2.82^{c} \pm 0.19$ & $3.47^{a} \pm 0.05$ & $2.97^{c b} \pm 0.22$ & $3.14^{a c} \pm 0.071$ & $2.83^{c} \pm 0.27$ \\
\hline
\end{tabular}

$a, b-$ statistically significant difference at $p \leq 0.05$

The liver serves a number of functions in the body's metabolism. It also aids excretion and secretion of metabolites. It is the site were detoxication processes occur and glucose is accumulated in the form of glycogen.

In order to determine the effect of the experimental preparations on the chemical composition of the turkey liver, samples of this organ were subjected to chemical determinations of the content of individual mineral elements. The results presented in Table 8 support the conclusion that $\mathrm{Cu}$ supplementation had a significant effect only on changes in $\mathrm{Cu}$ and $\mathrm{Zn}$ concentrations in a turkey's liver.

The application of copper, irrespective of its dose and chemical form, caused the enhanced accumulation of this element in livers of the turkeys. Despite the fact that copper competes with zinc for the site binding metallothioneins in cells of the intestinal mucosa (BRzozowsKa 1999, MAKARSKI, MAKARSKA 2009), the content of $\mathrm{Zn}$ was observed to increase significantly in the groups administered readily available $\mathrm{Cu}$ chelate with lysine. 
The content of mineral elements in the turkey liver

\begin{tabular}{|c|c|c|c|c|c|}
\hline \multirow{3}{*}{ Index } & Control & $\mathrm{CuSO}_{4}$ & $\begin{array}{l}\text { Chelate } \\
\mathrm{Cu} \text { - Lis }\end{array}$ & $\mathrm{CuSO}_{4}$ & $\begin{array}{l}\text { Chelate } \\
\mathrm{Cu} \text { - Lis }\end{array}$ \\
\hline & group I & group II & group III & group IV & group V \\
\hline & - & \multicolumn{2}{|c|}{$10 \mathrm{mg} \mathrm{Cu} \mathrm{dm}{ }^{-3} \mathrm{H}_{2} \mathrm{O}$} & \multicolumn{2}{|c|}{$20 \mathrm{mg} \mathrm{Cu} \mathrm{dm}{ }^{-3} \mathrm{H}_{2} \mathrm{O}$} \\
\hline $\mathrm{Cu}\left(\mathrm{mg} \mathrm{kg}{ }^{-1}\right)$ & $\begin{array}{c}4.971^{c} \\
\pm 0.447\end{array}$ & $\begin{array}{c}6.613^{a} \\
\pm 0.735\end{array}$ & $\begin{array}{l}17.308^{b} \\
\pm 1.534\end{array}$ & $\begin{array}{l}10.692^{c} \\
\pm 2.334\end{array}$ & $\begin{array}{l}25.325^{b} \\
\pm 0.933\end{array}$ \\
\hline $\mathrm{Zn}\left(\mathrm{mg} \mathrm{kg}^{-1}\right)$ & $\begin{array}{l}38.669^{c} \\
\pm 8.211\end{array}$ & $\begin{array}{c}33.050^{b c} \\
\pm 4.290\end{array}$ & $\begin{array}{c}61.683^{a} \\
\pm 10.938\end{array}$ & $\begin{array}{l}38.124^{c} \\
\pm 4.263\end{array}$ & $\begin{array}{l}50.083^{b} \\
\pm 6.512\end{array}$ \\
\hline $\mathrm{Ca}(\%)$ & $\begin{array}{c}0.022^{b} \\
\pm 0.001\end{array}$ & $\begin{array}{c}0.024^{a} \\
\pm 0.001\end{array}$ & $\begin{array}{c}0.020^{b} \\
\pm 0.001\end{array}$ & $\begin{array}{l}0.023^{a b} \\
\pm 0.001\end{array}$ & $\begin{array}{c}0.021^{b} \\
\pm 0.002\end{array}$ \\
\hline $\operatorname{Mg}(\%)$ & $\begin{array}{c}0.024^{b} \\
\pm 0.002\end{array}$ & $\begin{array}{c}0.028^{a} \\
\pm 0.003\end{array}$ & $\begin{array}{c}0.025^{b} \\
\pm 0.001\end{array}$ & $\begin{array}{c}0.023^{b} \\
\pm 0.003\end{array}$ & $\begin{array}{c}0.024^{b} \\
\pm 0.002\end{array}$ \\
\hline $\mathrm{Fe}\left(\mathrm{mg} \mathrm{kg}^{-1}\right)$ & $\begin{array}{l}106.542^{b} \\
\pm 13.265\end{array}$ & $\begin{array}{r}113.483^{b} \\
\pm 9.883\end{array}$ & $\begin{array}{l}129.500^{a} \\
\pm 12.470\end{array}$ & $\begin{array}{l}121.083^{b} \\
\pm 18.370\end{array}$ & $\begin{array}{c}114.667^{b} \\
\pm 2.976\end{array}$ \\
\hline $\mathrm{K}(\%)$ & $\begin{array}{c}0.345^{a} \\
\pm 0.016\end{array}$ & $\begin{array}{c}0.326^{a} \\
\pm 0.018\end{array}$ & $\begin{array}{c}0.338^{a} \\
\pm 0.017\end{array}$ & $\begin{array}{c}0.338^{a} \\
\pm 0.014\end{array}$ & $\begin{array}{c}0.283^{b} \\
\pm 0.029\end{array}$ \\
\hline $\operatorname{Mn}\left(\mathrm{mg} \mathrm{kg}^{-1}\right)$ & $\begin{array}{l}2.992^{a b} \\
\pm 0.240\end{array}$ & $\begin{array}{l}2.667^{a b} \\
\pm 0.436\end{array}$ & $\begin{array}{l}2.765^{a b} \\
\pm 0.259\end{array}$ & $\begin{array}{c}2.642^{b} \\
\pm 0.322\end{array}$ & $\begin{array}{c}2.908^{a} \\
\pm 0.672\end{array}$ \\
\hline $\mathrm{P}(\%)$ & $\begin{array}{c}0.274^{c} \\
\pm 0.018\end{array}$ & $\begin{array}{c}0.359^{a} \\
\pm 0.037\end{array}$ & $\begin{array}{c}0.303^{b} \\
\pm 0.014\end{array}$ & $\begin{array}{l}0.294^{b c} \\
\pm 0.014\end{array}$ & $\begin{array}{c}0.297^{b} \\
\pm 0.041\end{array}$ \\
\hline
\end{tabular}

$a, b, c-$ statistically significant difference at $p \leq 0.05$

\section{CONCLUSIONS}

1. Dietary supplementation of turkeys with $\mathrm{Cu}$ was observed to improve haematological blood markers, including $\mathrm{RBC}, \mathrm{Hb}$ and $\mathrm{Ht}$. These changes indicate improved health of the experimental turkeys.

2 . The activity of transferase-group enzymes determined in the study proved that the supplementation did not cause any negative changes in internal organs.

3. The copper supplements added to drinking water were observed to significantly affect lipid markers in blood serum. The level of cholesterol was reduced only after the administration of increased doses $(20 \mathrm{mg})$ of $\mathrm{Cu}$ in the organic form. In turn, the concentration of triacylglycerols in blood serum was positively affected by relatively low doses of this element. The above suggests the hypocholesterolemic properties of $\mathrm{Cu}$. 
4. The application of copper supplementation was found to reduce the concentration of uric acid.

5. The supplements did not cause any significant changes in the level of glucose. The level of this parameter was not raised until the highest, $20 \mathrm{mg}$ dose of $\mathrm{Cu}$ in the organic form was applied.

6. $\mathrm{Cu}$ supplementation as a chelate and in a $20-\mathrm{mg}$ dose caused enhanced accumulation of this element in the liver of turkeys.

\section{REFERENCES}

Boguszewska A., Pasternak K., Wieleba E., Marzec Z. 2003. Zinc and cooper in plasma and erythrocytes of patients with type II diabetes mellitus. Ann. UMCS, sect. D, 58, suppl., 13(20): 102-107.

BrzozowskA A. 1999. Interactions between iron zinc and their consequences for nutritional practice. Pol. J. Food Nutr. Sci., 7(48): 603-616.

Bunch R.J., Mc Call J.T., Speer V.C., Hays V.W. 1965. Copper supplementation for weanling pigs. J. Anim. Sci., 24: 905-1000.

Ewing H.P., Pesti G.M., Bakalli R.I., Menten J.F.M. 1998. Studies on the feeding of cupric sulfate pentahydrate, cupric citrate, and cooper oxychloride to broiler chickens. Poult. Sci., 77: 445-448.

Failla M.L., Hopkins R.G. 1998. Is low copper status immunosuppressive?. Nutr. Rev., 56(1): 59-64.

HARMS R.H., BURESH R.E. 1986. Influence of three levels of copper on the performance of turkey poults with diets containing two sources of methionine. Poult. Sci., 66: 721-724.

JAMroz D., Potkański A. 2004. Żywienie zwierząt i paszoznawstwo. Podstawy szczegótowe zywienia zwierzat [Animal nutrition and feed science. Detailed guidelines for animal nutrition]. Wyd. Nauk. PAN, Warszawa, pp. 329-340. (in Polish)

JAMroz D. 1990. Biologiczna rola sktadników mineralnych $w$ żyieniu drobiu [The biological role of mineral components in poultry feeding]. Drobiarstwo, 23(1/3): 7-11. (in Polish)

Kratzer H.F., Latshaw D.J., Lesson S.L., Moran E.T., Parsons C.M., Sell J.L., Waldroup P.W. 1994. Nutrient requirements of poultry. Ninth Revised Edition. Nat. Acad. Press, Washington, pp. 35-39.

KuźLik-Wyrostek M., Makarski B. 2009. Wptyw Cu i kwasu mlekowego na wskaźniki hematologiczne $i$ biochemiczne krwi oraz modyfikacje flory bakteryjnej przewodu pokarmowego indyków [Effect of $\mathrm{Cu}$ and lactic acid on haematological and biochemical blood indices and on modification of microbial flora in the gastrointestinal tract of turkeys]. J. Elementol., 14(3): 53-53. (in Polish).

MAKARSki B., ZADURA A. 2006. Changes in the content of mineral components in tissues of turkeys receiving a supplement of Cu chelate with lysine. J. Elementol., 11(2): 183-190.

MAKARSKi B., MAKARSKA E. 2009. Copper transformations and their influences on turkeys' health. Pierwiastki w środowisku i życiu człowieka. Lublin, s. 199-217.

Makarski B., Polonis A., Czech A., Sembratowicz I. 2002. Wptyw miedzi pochodzqcej ze zwiqzków nieorganicznych $i$ chelatów na wskaźniki krwi $i$ wyniki produkcyjne indyków [Effect of copper from inorganic compounds and chelates on blood aparameters and production performance of turkeys]. Ann. UMCS, sect. EE, 20(41): 287-293. (in Polish)

Noy Y., Frisch Y., Rand N., Sklan D. 1994. Trace mineral requirements in turkeys. World's Poult. Sci., 50: 253-268. 
Noyce J.O., Michels H., Keevil C. W. 2006. Potential use of copper surfaces to reduce survival of epidemic meticillinresistant Staphylococcus aureus in the health care environment. J. Hosp. Infect., 63(3): 289-297.

OlejNiK M., SzPRengier-Juszkiewicz T., ŻMudziK J. 2009. Kokcydiostyki w żywności i paszach nowe uwarunkowania prawne [Coccidiostats in food and feeds - new legal regulations]. Med. Wet., 65(12): 807-811. (in Polish)

Pesti G.M., Bakali R.I. 1996. Studies on the feeding of cupric sulfate pentahydrate and cupric citrate to broiler chickens. Poult. Sci., 75: 1086-1091.

Polonis A., Makarski B., Praczyk M., Trawińska B. 1999. Badanie retencji miedzi z różnych zwiazków $w$ wybranych tkankach indyków [Studying retemtion of copper from different compounds in selectd turkey tissues]. XII Międz. Młodzież. Symp. Drob. WPSA, Lublin, s. 59-63. (in Polish)

Smulikowska S. 1996. Normy żywienia drobiu [Polutry nutrition standards]. PAN, Warszawa. (in Polish)

Ward T.L., Watkins K.L., Southern L.L. 1995. Interactive effects of dietary copper, water copper and Eimeria spp. infection on growth, water intake and plasma and liver copper concentrations of poults. Poult. Sci., 74: 502-509. 